\title{
LONG TERM STUDY OF COMPETITION BETWEEN TWO CO-OCCURRING CRAYFISH SPECIES, THE NATIVE ASTACUS ASTACUS L. AND THE INTRODUCED PACIFASTACUS LENIUSCULUS DANA, IN A FINNISH LAKE.
}

\author{
K. WESTMAN (1), R. SAVOLAINEN (2)
}

(1) Finnish Game and Fisheries Research Institute, Aquaculture, P.O. Box 6, 000721 Helsinki, Finland, fax 0205751 201, e-mail : kai.westman@rktl.fi

(2) Finnish Game and Fisheries Research Institute, Laukaa Fisheries Research and Aquaculture, 41360 Valkola, Finland, fax 0205751 519, e-mail : riitta.savolainen@rktl.fi

\section{ABSTRACT}

Since 1893, crayfish plague, Aphanomyces astaci Schikora, has devastated Finland's most productive populations of the native noble crayfish, Astacus astacus, causing great losses to once very valuable fisheries and exports. Efforts to halt the spread of the plague having failed, it was decided in the late 1960s to attempt to revive crayfish production and fisheries by introducing the plague-resistant North American signal crayfish, Pacifastacus leniusculus, into infected waters. So far $P$. leniusculus has been stocked in more than 300 waterbodies and is currently known to reproduce in roughly 100 of them. In some lakes both species live in sympatry. We have studied the interactions of co-existing $A$. astacus and $P$. leniusculus in the small lake of Slickolampi for 30 years. According to annual trap catches and population size estimates, A. astacus was clearly dominant up to the end of the 1980 s, but in the 1990s $P$. leniusculus became dominant. In the last sampling, in August 1999, it accounted for $>98 \%$ of total catches. In the course of three decades, then, $P$. leniusculus has almost completely replaced $A$. astacus.

$P$. leniusculus has many of the characteristics commonly found in the successful crayfish invader. Our comparative studies in this lake show that $P$. leniusculus individuals grow considerably more rapidly, and that females reproduce for the first time at a younger age, attain reproductive activity at a larger size, and have greater fecundity in all size groups than $A$. astacus. The greater abundance of chelae injury in $A$. astacus than in $P$. leniusculus and the increase in injuries with expansion of the $P$. leniusculus population point to agonistic encounters in which $P$. leniusculus is dominant.

Long-term data on co-existing $A$. astacus and $P$. leniusculus demonstrate that they cannot live in sympatry without competition in which $P$. leniusculus with its larger body and chela size, faster growth, more aggressive behaviour and greater fecundity would be the stronger. However, a similar weakening of the $A$. astacus population at sites with only a minor population of $P$. leniusculus suggests that the elimination of $A$. astacus is due, not to competitive exclusion alone, but to a combination of several interacting mechanisms and that the ultimate reason for the collapse of $A$. astacus is the almost complete cessation of successful reproduction as a result of reproductive interference between the two species. It is therefore futile to stock productive $A$. astacus waters with plague-free $P$. leniusculus in the expectation of better total catches. $P$. leniusculus should be introduced only into 
chronically plague-infected waters. The preservation of the native $A$. astacus, along with efforts to secure its valuable catches, requires above all the formulation of an action plan and a greater input into research, especially on crayfish plague control, crayfish management, and interactions between $P$. leniusculus and $A$. astacus.

Key-words: freshwater decapods, Astacus astacus, Pacifastacus leniusculus, species interactions, competition, replacement, management.

\section{ÉTUDE SUR LE LONG TERME DE LA COMPÉTITION ENTRE DEUX ESPÈCES D'ÉCREVISSES COEXISTANTES, L'ESPĖCE NATIVE ASTACUS ASTACUS L. ET L'ESPÈCE INTRODUITE PACIFASTACUS LENIUSCULUS DANA, DANS UN LAC FINLANDAIS.}

\section{RÉSUMÉ}

Depuis 1893, la peste de l'écrevisse, Aphanomyces astaci Schicora, a détruit la plupart des belles populations finlandaises d'écrevisse à pattes rouges, Astacus astacus, causant de fortes pertes à la fois à la pêche commerciale et aux exportations. Les efforts pour stopper la propagation de la peste ayant échoué, il a été décidé à la fin des années 1960 de tenter de faire revivre la production d'écrevisses et la pêche, en introduisant l'écrevisse signal d'Amérique du Nord, résistante à la peste, Pacifastacus leniusculus, dans les eaux infectées. Depuis, $P$. leniusculus a été introduite dans plus de 300 sites et est actuellement connue pour se reproduire dans, approximativement, 100 d'entre eux. Dans quelques lacs, ces deux espèces vivent en sympatrie. Nous avons étudié les interactions de la coexistence d'A. astacus et $P$. leniusculus dans un petit lac, Slickolampi, depuis 30 ans. Selon les captures annuelles par nasses et les estimations de la taille des populations, $A$. astacus était clairement dominant jusqu'à la fin des années 1980, mais depuis $1990 P$. leniusculus l'est devenu. Au cours du dernier échantillonnage, en août 1999, $P$. leniusculus comptait pour plus de $98 \%$ des captures totales. Au cours de trois décennies, $P$. leniusculus a presque complètement remplacé $A$. astacus.

$P$. leniusculus possède beaucoup de caractéristiques rencontrées communément chez les espèces d'écrevisses invasives. Dans ce lac, nos études comparatives montrent que les individus de $P$. leniusculus croissent considérablement plus rapidement que ceux d'A. astacus, et que les femelles se reproduisent pour la première fois à un âge plus jeune avec une taille plus grande, et ont une plus grande fécondité pour l'ensemble des classes de taille que celles d'A. astacus. La plus grande abondance des mutilations de pinces chez $A$. astacus que chez $P$. leniusculus, ainsi que l'augmentation des mutilations avec l'expansion de la population de $P$. leniusculus, montrent que lors des rencontres interspécifiques, $P$. leniusculus est dominant.

Les données sur le long terme sur la coexistence entre $A$. astacus et $P$. leniusculus démontrent qu'ils ne peuvent vivre en sympatrie sans compétition car $P$. leniusculus, ayant une plus grande taille, de plus longues pinces, une croissance plus rapide, une agressivité plus importante et une fécondité plus grande, serait le plus fort. Cependant, un affaiblissement semblable des populations d'A. astacus dans des sites ayant une faible population de $P$. leniusculus suggère que l'élimination d' $A$. astacus est due, non seulement à une exclusion compétitive, mais aussi à une combinaison de plusieurs mécanismes reliés et que la raison finale de l'effondrement d'A. astacus est due à l'arrêt presque complet du succès de la reproduction à cause de croisements interspécifiques non fertiles entre les deux espèces. II est donc dérisoire d'introduire dans un site non infecté par la peste, produisant $A$. astacus, $P$. leniusculus dans l'espoir de plus fortes captures totales. $P$. leniusculus devrait être introduite seulement dans des eaux chroniquement infectées. 
La conservation de l'écrevisse indigène $A$. astacus qui nécessite des efforts pour limiter le nombre de captures, exige surtout la formulation d'un plan d'action et une plus grande participation de la recherche, principalement, pour contrôler la peste de l'écrevisse, pour améliorer la gestion des populations et mieux comprendre les interactions entre $P$. leniusculus et $A$. astacus.

Mots-clés: Décapodes d'eaux douces, Astacus astacus, Pacifastacus leniusculus, interaction entre espèces, compétition, remplacement, gestion.

\section{INTRODUCTION}

Due to the vast number of inland waters, Finland is particularly well-suited for largescale crayfish production as was shown by the huge noble crayfish, Astacus astacus, catches at the turn of the century. At its height, in 1900, the crayfish catch totalled 20 million specimens per year (JÄRVI, 1910). Equivalent to some 850 tonnes, this is probably the largest amount of $A$. astacus ever caught in a European country (WESTMAN and WESTMAN, 1992).

The crayfish plague, Aphanomyce astaci, reached Finland in 1893. It eventually devastated the most productive populations of $A$. astacus, causing great losses to once very valuable fisheries and exports (e.g. WESTMAN, 1973, 1991) and preventing Finland's excellent potential for crayfish production from being exploited. Efforts to contain the plague failed. With no new methods of combating it in view and considering the promising results yielded by stocking the plague-resistant North American signal crayfish, Pacifastacus leniusculus, in Sweden (e.g. ABRAHAMSSON, 1964 ; SVÄRDSON, 1965), it was decided in the late 1960s to introduce this species into Finland in order to revive crayfish production in the innumerable plague-waters.

Even though $P$. leniusculus has been introduced into several thousand waters in at least 21 European countries (e.g. LOWERY and HOLDICH, 1988; WESTMAN and WESTMAN, 1992 ; GHERARDI and HOLDICH, 1999), very few studies have been published on interactions between sympatric $P$. leniusculus and $A$. astacus populations (SVÄRDSON, FÜRST and FJÄLLING, 1991 ; SÖDERBÄCK, 1993, 1995 ; WESTMAN, SAVOLAINEN and PURSIAINEN, 1995). The main reason is that $P$. leniusculus has either been introduced into plague-waters or the stocked specimens have been carriers of the plague. The shortage of long-term monitoring studies is particulary regrettable, as these are essential when new species are introduced to ensure that even gradual interactions with and impacts on resident native species are detected.

From 1970 to 1999, the development of $P$. leniusculus and $A$. astacus was monitored in Slickolampi, a small, enclosed lake in Finland. Although the $P$. leniusculus population grew steadily, $A$. astacus was dominant until the late 1980 s after where it unexpectedly began to decrease heavily and that of $P$. leniusculus to increase, suggesting that the introduced exotic species was replacing the native one.

The aims of the present paper were to consider how the stocks of these two species have developed during the period of over 30 years they have co-existed in this lake and to identify the mechanisms underlying the rapid replacement of $A$. astacus by $P$. leniusculus in recent years. Such information is badly needed as we can expect more and more plague-free $P$. leniusculus to be stocked or to spread into waters with an existing A. astacus population, not only in Finland but in other European countries, too. If the major factors governing the invasions could be identified, this would enable to predict the future spread and impact of the invading species and thus also devise ways of preserving the native species. 


\section{MATERIAL AND METHODS}

Slickolampi (hereafter referred to as Lake $S$ ) is an oligotrophic forest lake without inlets or outlets in a natural state in southern Finland (Pohja $60^{\circ} 01^{\prime} \mathrm{N}, 23^{\circ} 34^{\prime} \mathrm{E}$ ). Its area is $4.2 \mathrm{ha}$, shoreline $1000 \mathrm{~m}$, and maximum depth $5 \mathrm{~m}$.

The ice-free period usually lasts for about 200 days, from early May to late November. The temperature needed for the growth of crayfish, $>10^{\circ} \mathrm{C}$ (e.g. AIKEN and WADDY, 1992), prevails for about 5 months in normal years and reaches its peak, about $20{ }^{\circ} \mathrm{C}$, in July. The temperature needed for reproduction, $>15^{\circ} \mathrm{C}$ (ABRAHAMSSON, 1971), prevails for about 3 months.

The water is relatively clear (colour $15-40 \mathrm{mgPt} / \mathrm{l}$, Secchi depth of visibility $3.5 \mathrm{~m}$ ) and low in humus; the $\mathrm{O}_{2}$ content is high an pH tends to be periodically rather low (range 5.7-7.1). The $\mathrm{Ca}$ concentration is relatively high under Finnish conditions (range 4.4$6.3 \mathrm{mg} / \mathrm{l})$. No changes in water quality were recorded during the study period.

The lake supports fish species typical of Finnish waters : perch (Perca fluviatilis), roach (Rutilus rutilus), pike (Esox lucius) and rudd (Scardinius erythrophthalmus).

A. astacus disappeared for the first time in the 1930s and again in 1960. Both times the disappearance was attributed to crayfish plague. On 15 July 1971, the senior author introduced 900 cultured $2^{\text {nd }}$ stage $(10 \mathrm{~mm}) P$. leniusculus imported from Sweden (Simontorp Akvatiska Avelslaboratorium, Blentarp). These were the offspring of adults imported from Lake Tahoe, CA, in autumn 1969 (BRINCK, 1983). A. astacus individuals were unexpectedly caught in the lake during test trappings in autumn 1971. Both crayfish populations remained unexploited until 1979 and $A$. astacus again after 1995.

The relative abundances of the trappable $A$. astacus and $P$. leniusculus subpopulations were monitored by a standardised sampling procedure in 1970-1999 using catch per unit effort (CPUE = crayfish per trap night) as an indicator of crayfish relative abundance on different occasions and at different sites.

The sampling procedure was standardised to permit calculations of catch/trap statistics. To avoid catch bias, and also the trappability problems due to variations in crayfish activity and catchability (e.g., MASON, 1975 ; FLINT, 1977 ; ABRAHAMSSON, 1983), we used a 2-mouthed cylinder trap, from 1978 with narrowed entrances (Evo) from which the crayfish could not escape (WESTMAN, PURSIAINEN and WILKMAN, 1979 ; FJÄLLING, 1995) and took the samples only in late summer during an intermoult period of high activity for both sexes. The bait was fresh or deep-frozen roach.

Trapping took place along the entire shore except in 1970-1975, when only the $P$. leniusculus stocking area was sampled. The samples were taken on 109 nights (18 168 trap nights, annual variation 30-1 400) in August and on a few nights in early September.

To ensure that the traps were always placed in the same location, they were fastened at $5 \mathrm{~m}$ intervals to a floating nylon line located about 2-3 $\mathrm{m}$ from the shore (depth interval 0.5-3 m). This trap spacing was based on the effective trapping radius of $2.5 \mathrm{~m}$ presented in the study of ABRAHAMSSON and GOLDMAN (1970), in which the capture range of a 2-mouthed cylinder trap was about $13 \mathrm{~m}^{2}$. The sampling technique is described at length elsewhere (WESTMAN, 2000).

Population sizes were estimated with the mark-recapture method in 1979-1988 and 1990-1994 (but not $A$. astacus in 1985). After 1994 the catch of $A$. astacus was so small that we stopped the population size estimates. The Petersen method (RICKER, 1975) was used to convert the mark-recapture data into estimates of the trappable subpopulations 
sizes. To avoid bias due to sex ratio differences, the estimates were made during the period of high activity for males and females in late summer. Trapped crayfish were marked by electric cauterisation (ABRAHAMSSON, 1965) with a portable apparatus developed specifically for field marking (WESTMAN and PURSIAINEN, 1979). Because the populations were sparse throughout the study, the sexes were pooled. To avoid the behavioural dominance of large individuals in trap catches (ABRAHAMSSON, 1966 ; MASON, 1975), and thus also in the population estimates, from 1980 onwards the catch of the first trapping night was collected in a crayfish basket by the double marking-recapture method.

Sex, carapace length (CL), missing chelae and markings were recorded. For reasons given earlier (WESTMAN, SAVOLAINEN and PURSIAINEN, 1999), CL measured with vernier calipers to the nearest $\mathrm{mm}$ from the tip of the rostrum to the posteriomedian margin of the cephalothorax, i.e. "standard carapace length ", (FITZPATRICK, 1977) or "total carapace length", (TCL; AIKEN and WADDY, 1992) was converted to TL (regression equations presented in WESTMAN, 2000). TL is the length from the tip of the rostrum to the end of the telson of the stretched abdomen. Unless otherwise stated, the lengths given in the text are TL.

To make commercial use of the stocks and examine their ability to sustain harvesting, all « legally sized » ( $\geq 100 \mathrm{~mm} \mathrm{TL}$ ) crayfish caught at recapture were removed in 1979-1994. Due to the alarming depletion of the A. astacus population, however, no individuals of that species were removed after 1994. In an attempt to reduce the dominance of $P$. leniusculus over $A$. astacus, the catch size limit of $P$. leniusculus was lowered to $90 \mathrm{~mm}$ in 1995.

\section{RESULTS}

\section{Changes in the abundance of Astacus astacus and Pacifastacus leniusculus populations}

A total of 7567 adult $A$. astacus were sampled. The first specimens (17, about 90$100 \mathrm{~mm}$ ) were unexpectedly caught in autumn 1971. From the growth rate of $A$. astacus (WESTMAN, SAVOLAINEN and PURSIAINEN, 1993a), they would appear to have been $5+$ or even older. Reproduction thus started in the 1960s.

The mean CPUE was quite low throughout the 1970s, i.e. 0.3-0.7 (Figure 1), but abruptly catches nearly doubled, peaking in 1981 at 1.4 individuals per trap and night. After that catches declined and returned to their previous level. In the 1990s, there was a sudden catastrophic drop in catches, and in 1999 only 15 specimens were caught (CPUE 0.02).

The size of the trappable $A$. astacus subpopulation was estimated to have been about $600-800$ specimens at the end of the 1970s and to have reached its maximum, $1400-1500$, in 1981 and 1982. In the 1990s, the population declined heavily, being only about 190 individuals at the last estimate, made in 1994 (Figure 2). The mean density was therefore $0.6-0.8$ individuals per shore metre in the late 1970s, 1.5 in the peak year, 1981, but only 0.2 in the 1990 s. 


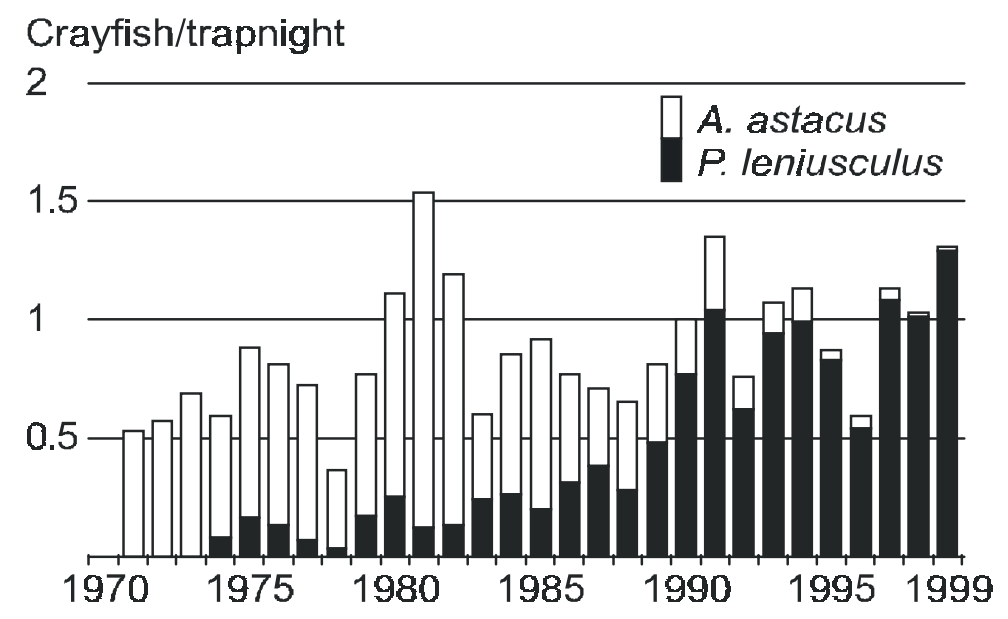

Figure 1

Mean trap catches (crayfish/trap/night) of Astacus astacus and Pacifastacus leniusculus in Slickolampi in late summer in 1970-1999. In 19701975 only some of the shores were trapped. Harvesting ( $\geq 100 \mathrm{~mm}$ individuals) began in 1979. No $A$. astacus were removed after 1994, the year the catch size limit of $P$. leniusculus were lowered to $90 \mathrm{~mm}$.

\section{Figure 1}

Moyenne des captures par nasses (écrevisse/nasse/nuit) d'Astacus astacus et $P$. leniusculus à Slickolampi durant l'été entre 1970-1999. Entre 1970 et 1975, seulement quelques rivages ont été prospectés. Des captures d'individus, de taille supérieure à $100 \mathrm{~mm}$, ont commencé à partir de 1979. Aucune Astacus astacus n'a été retirée après 1994, l'année où la limite de la taille de capture pour $P$. leniusculus a été descendue à $90 \mathrm{~mm}$.

A total of $8541 P$. leniusculus were trapped. Judging by their size, the first specimens (9 males, 115-132 mm) caught, in 1974, were from the stocking assignment. In 1976, reproduction was observed with certainty, as the catch comprised individuals of two size groups ; $130-140 \mathrm{~mm}(\mathrm{~N}=8)$ and $80-110 \mathrm{~mm}(\mathrm{~N}=22)$. Aged $5+$, the former were most probably stocked but the latter, judging by the growth rate of $P$. leniusculus (WESTMAN, SAVOLAINEN and PURSIAINEN, 1993a), were $2+$ or $3+$, i.e. hatched in 1974 or 1973.

The mean CPUE was very low throughout the 1970 s and most of the 1980 s, i.e. 0.10.3. In the 1990s, however, it increased sharply. The largest catch to date, 1.3, was taken in 1999 (Figure 1).

The size of the catchable subpopulation was very small, only about 100-300 specimens, until the mid-1980s. Thereafter the population size increased vigorously and in 1990 was estimated for the first time to exceed that of $A$. astacus. At its peak, in 1993, the $P$. leniusculus population comprised about 1000 individuals (Figure 2). The mean density in the late 1970s was therefore $0.1-0.3$ and in the peak year about 1.0 crayfish per shore metre. 


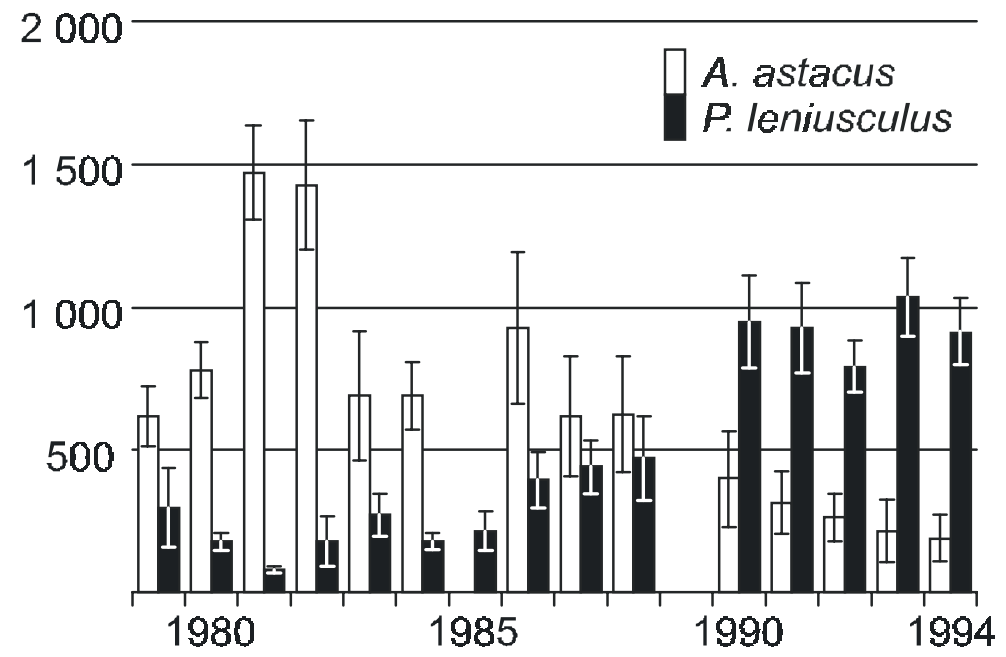

Figure 2

Population size of trappable Astacus astacus and Pacifastacus leniusculus in Slickolampi estimated by Petersen's mark-recapture method in 1979-1994. Vertical bars are confidence limits $\pm 95 \%$. If the confidence limit lines of two estimates do no overlap the difference between estimates was considered significant $(p<0.05)$.

\section{Figure 2}

Taille de la population d'Astacus astacus et de $\boldsymbol{P}$. leniusculus capturable à Slickolampi estimée par la méthode de marquage-recapture de Petersen entre 1979-1994. Les traits verticaux sont les limites de confiance à $\pm 95 \%$. Si les traits de limite de confiance entre les deux estimations ne se superposent pas la différence entre les estimations est considérée significative $(p<€ 0.05)$.

\section{Species composition}

The combined CPUE of both species was at its maximum in 1981-1982 (mean 1.21.5 ; Figure 1 ). Due to the decline in the $A$. astacus population the total crayfish abundance also declined in the 1980s but concomitant with the marked increase in the $P$. leniusculus population, the combined mean CPUE rose once more in the 1990s, ranging from 0.6 to 1.4. The size of the total catchable $A$. astacus and $P$. leniusculus subpopulations was greatest in 1982, about 1600 specimens (i.e. 1.6 individuals per shore metre). In 19861994 there was little change in the total crayfish population (variation 1000-1300 individuals), but the proportions of the species changed (Figure 2).

According to catches, A. astacus was dominant throughout the 1970s and almost the entire 1980s (Figure 3). At the end of the 1980s, however, there was a shift in abundance from $A$. astacus to $P$. leniusculus, and in the 1990s $P$. leniusculus became clearly dominant, accounting in the final years of the 1990s for $>98 \%$ of the total catch. Thus, $P$. leniusculus, which originated from a minor juvenile stocking, had nearly totally replaced $A$. astacus in the course of 30 years (Figures 1,3 ). 


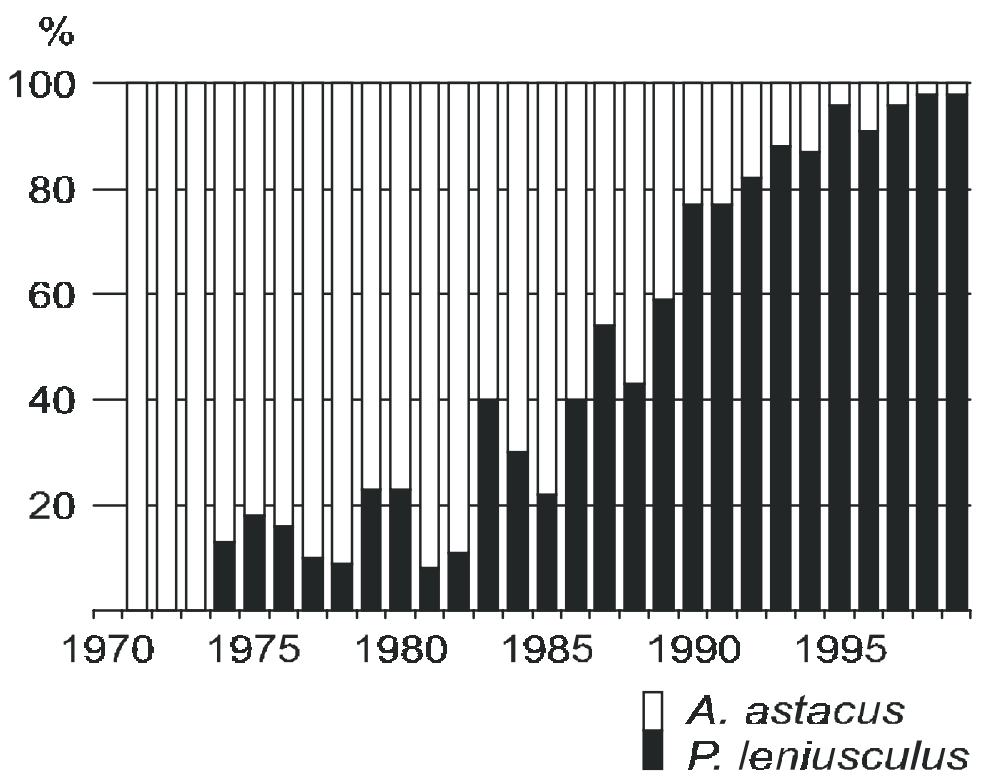

Figure 3

Changes in relative abundance of Astacus astacus and Pacifastacus leniusculus in Slickolampi in 1970-1999.

\section{Figure 3}

Changements dans l'abondance relative d'Astacus astacus et Pacifastacus leniusculus à Slickolampi entre 1970-1999.

\section{Harvest}

In $1979-1994$ a total of $874 \geq 100 \mathrm{~mm}$ A. astacus was exploited $(25 \%$ of the trappable $A$. astacus catch of 3452 in these years). The number of females removed was 262 (13\% of the total female catch) and of males $612(45 \%)$, i.e. the number of exploitable males was about 2.4 times that of females. In the first 4 years (1979-1982), the proportions of «legal sized " individuals were high $(27-36 \%$ of the annual catch), but thereafter they declined heavily, and in 1983-1989 no more than $9-21 \%$ of the catch was exploitable.

The number of $P$. leniusculus harvested was 1389 . Their proportion of the trappable catch (2898) was nearly double (c. $48 \%$ ) that of $A$. astacus. The number of removed females was 692 (44\% of the total female catch) and of males $697(55 \%)$, i.e. unlike in $A$. astacus about the same number of both sexes were harvestable. In $P$. leniusculus the average catch of $\geq 100 \mathrm{~mm}$ females per year was about 3.5 times that of trappable $A$. astacus females. A decline similar to that in $A$. astacus was not seen in the proportion of exploitable $P$. leniusculus individuals caught after the start of harvesting.

Although $A$. astacus accounted for a larger proportion of the combined catch of trappable individuals in 1979-1994 (55\%), its share of the total $\geq 100 \mathrm{~mm}$ harvest was smaller (39\%). Correspondingly, P. leniusculus accounted for a smaller proportion of the total catch of trappable individuals (45\%) but for a considerably larger proportion of exploitable individuals $(61 \%)$, i.e. a smaller trappable population produced more exploitable specimens under identical conditions. 


\section{DISCUSSION}

Long-term data on the dynamics of co-existing $A$. astacus and $P$. leniusculus in Lake $S$ demonstrate clearly that these species cannot live in sympatry without competition in which P. leniusculus is the stronger. A. astacus was distinctly dominant in the 1970 s and throughout almost the entire 1980s. At the end of the decade, however, there was a shift in abundance from $A$. astacus to $P$. leniusculus and in the 1990s the latter became the dominant species. As the 1990s drew to a close $P$. leniusculus was already accounting for over $98 \%$ of pooled catches. Hence, rather than adding to the existing fauna in this lake, $P$. leniusculus has replaced $A$. astacus. Unless protected, the native species can be expected to disappear from Lake $S$ altogether. Similar losses have been recorded in Sweden, where $P$. leniusculus has outcompeted $A$. astacus in some lakes (FÜRST, 1977 ; SVÄRDSON, FÜRST and FJÄLLING, 1991; FISKERIVERKET, 1993 ; SÖDERBÄCK, 1993). However, in waters where populations have been able to grow denser without substantial competition the situation has been stable (FJÄLLING and FÜRST, 1988).

Competition between $P$. leniusculus and $A$. astacus is to be expected as in their own natural habitats they have developed convergently in an ecologically homologous manner in many respects, with high interspecific overlap along important niche dimensions. The two species are similar in size, morphology and life history and also their life cycles are synchronous (ABRAHAMSSON, 1971; CUKERZIS, 1988; LOWERY, 1988 ; FISKERIVERKET, 1993 ; SÖDERBÄCK, 1993, 1995). Further they share omnivorous food preferences and a nocturnal activity pattern (e.g. FLINT 1975 ; ABRAHAMSSON, 1983 ; HESSEN, 1989). Moreover they seem to a great extent to prefer the same types of biotope (WESTMAN 2000).

$A$. astacus and $P$. leniusculus have indeed so many traits in common that when compelled to co-exist in an environment like Lake S, with a limited amount of shelterproviding habitats and other resources, they cannot avoid interspecific competition. $P$. leniusculus must be very competitive compared with $A$. astacus because stocking with as few as $9002^{\text {nd }}$ stage individuals, which corresponds to the production of no more than a few females of large size (SAVOLAINEN, WESTMAN and PURSIAINEN, 1997), was sufficient for a $P$. leniusculus population to expand even when all the niches in the stocking area were already occupied by $A$. astacus.

For one species to replace another, the invader must perform better than the native. An interesting question, and one that is particulary important for the protection of $A$. astacus, is why and in which characteristics $P$. leniusculus is a stronger competitor than A. astacus. In earlier studies (WESTMAN, SAVOLAINEN and PURSIAINEN, 1993a, b; SAVOLAINEN, WESTMAN and PURSIAINEN, 1997), we observed that $P$. leniusculus both grows faster and reproduces better in Lake $S$, giving this species a clear competitive advantage over $A$. astacus. Another factor that may have contributed to the weakening of the $A$. astacus population is aggressive interactions with $P$. leniusculus. The latter tends to have larger chelae and, under laboratory conditions (TSUKERZIS, 1976 ; SÖDERBÄCK, 1991 ; HOLDICH et al., 1995a), has been much more successful than $A$. astacus in competitive encounters. The relatively greater chelae injury in $A$. astacus than in $P$. leniusculus in Lake S (WESTMAN, 2000) indicate that agonistic interspecific encounters also occur under natural conditions in which $P$. leniusculus is dominant. This is in accordance with the observations of LAURENT and PARIS (1994) and SÖDERBÄCK (1995). As a result, the weaker $A$. astacus is presumably displaced, at least to some extent, from preferred food resources and shelter-providing habitats to inferior biotopes, which would in turn increase predation and other risks (e.g. GARVEY and STEIN, 1993 ; LODGE and HILL, 1994). The smaller mean size of $A$. astacus in areas with the densest $P$. leniusculus population (WESTMAN, 2000) implies that competition for food and habitat has inhibited growth in $A$. astacus. The agonistic interactions seen in adults presumably occur in juveniles, too, as juveniles of both species live in the same restricted areas of 
Lake S (WESTMAN, SAVOLAINEN and PURSIAINEN, 1993a) and thus also have to compete for resources. The faster individual growth rate of $P$. leniusculus than of $A$. astacus from the very beginning (WESTMAN, SAVOLAINEN and PURSIAINEN, 1993a; JONSSON, 1995; SÖDERBÄCK, 1995) reinforces the observed dominance of P. leniusculus juveniles (SÖDERBÄCK, 1991, 1994a ; HOLDICH et al., 1995a).

It is indeed likely harvest ( $\geq 100 \mathrm{~mm}$ specimens) and competition with the in many ways more competent $P$. leniusculus were initially the most important reasons for the weakening of the $A$. astacus population. However, the similar weakening of the $A$. astacus population at sites with only a minor $P$. leniusculus population suggests that the elimination of $A$. astacus by $P$. leniusculus is not adequately explained by competitive exclusion. It does not, for instance, explain why in the early 1990s $A$. astacus was still present in the most preferred biotypes, in which $P$. leniusculus was many times more abundant than $A$. astacus, nor why $A$. astacus was not much denser in habitats in which $P$. leniusculus was noticeably less dense than in the most preferred sites; in other words, why did $A$. astacus not « withdraw » into habitats that $P$. leniusculus appeared to avoid.

The crash in the $A$. astacus population implies an almost complete cessation of successful reproduction throughout the lake. Current knowledge suggests that the most likely explanation for the failed recruitment of new generations was reproductive interference between $A$. astacus and $P$. leniusculus. Under experimental conditions these species will mate but produce only sterile eggs (SÖDERBÄCK, 1994b; HOLDICH et al., 1995b). If recruitment is reduced in both species, the outcome will be less serious for $P$. leniusculus, which has a higher capacity for population increase, than $A$. astacus, as observed in our earlier studies in Lake S (WESTMAN, SAVOLAINEN and PURSIAINEN, 1993a,b ; SAVOLAINEN, WESTMAN and PURSIAINEN, 1997) and also by SÖDERBÄCK $(1993,1995)$. When the two populations were equally abundant, intermating presumably did not play a very important role. As the $A$. astacus population continued to decline, however, reproductive interference assumed increasing prominence as a replacement mechanism. In the present situation, in which the catch of $A$. astacus accounts for only a few percent of the total, the likelihood of finding conspecific mates is so low that practically all matings are with $P$. leniusculus. Contributory factors have been the relatively greater culling of $\geq 100 \mathrm{~mm} A$. astacus males by harvesting than of $P$. leniusculus, and the dominance of the competition for mates by the bigger $P$. leniusculus with their larger chelae and more aggressive tendencies (cf. STEIN, 1976). Similar intermating has been encountered in other Astacidae (HOLDICH et al., 1995b) and also in Cambaridae in which species producing more juveniles and having faster growth (like $P$. leniusculus) have suffered less from impaired reproductive success due to intermating between species in sympatry (e.g. CAPELLI and MUNJAL, 1982 ; BUTLER and STEIN, 1985 ; HOBBS III, JASS and HUNER, 1989 ; LODGE and HILL, 1994). It is noteworthy that SÖDERBÄCK $(1993,1994 b, 1995)$ has attributed the near extinction of $A$. astacus co-occurring in a Swedish lake with $P$. leniusculus to the combined effect of interspecific competition, predation and reproductive interference.

In summary, $P$. leniusculus appears to have many of the characteristics, e.g. larger body and chela size, faster growth, aggressive behaviour, greater fecundity and overall thermal tolerance (RUTLEDGE and PRITCHARD, 1981 ; FIRKINS and HOLDICH, 1993), found in successful invaders (reviewed e.g. by BUTLER and STEIN, 1985 ; MATHER, 1990 ; LODGE and HILL, 1994 ; LINDQVIST and HUNER, 1999). In P. leniusculus, these characteristics may interact in many ways, for example, its faster growth rate and greater fecundity may be due to greater aggressiveness and activity, securing continuous access to food resources and shelter-giving habitats. However, the more species displacement is studied, the more complex the subject turns out to be. For example, the competitive superiority of $O$. rusticus over congeners may be due not only to the aforementioned characteristics but also to the interaction of competition with diel fluctuation in predation 
risk (HILL and LODGE, 1994), its greater responsiveness to food odours (WILLMAN, HILL and LODGE, 1994) and its higher weight-specific consumption rates (OLSEN et al., 1991).

Similar features may also reinforce the dominance of $P$. leniusculus, as NYSTRÖM (1999) and NYSTRÖM, BRÖNMARK and GRANELI (1999) have recently observed that $P$. leniusculus has a greater weight-specific consumption rate than $A$. astacus.

It is likely that $A$. astacus will be driven into extinction in Lake $S$ unless the management actions introduced reverse the trend. However, neither the termination of $A$. astacus harvesting in 1994 nor the lowering of the catch size limit of $P$. leniusculus to $90 \mathrm{~mm}$ in 1995 appeared to have had a marked effect on the populations of either species by the end of the 1990s. Nevertheless, as MOMOT (1993) observed in O. virilis, increased exploitation may change the dynamics of the $P$. leniusculus population by altering the mechanisms controlling population size. This will be seen in the coming years.

\section{CONCLUSIONS AND IMPLICATIONS FOR MANAGEMENT}

Comparative studies in Lake $S$ clearly indicate that $P$. leniusculus grows more rapidly than the native $A$. astacus, reaches a larger size, reproduces at a younger age and retains its reproductive capacity to a greater size than the latter, produces more ovarian eggs and sustains harvesting well (> 95-100 mm individuals) (references in WESTMAN, 2000). It may thus develop into a permanent renewable natural resource in the numerous waters affected by crayfish plague in Finland.

Paradoxically, the good plague-resistance of $P$. leniusculus causes the biggest problems as the species may spread the plague. This is a real danger even though new $A$. astacus populations become infected in Finland every year mainly for several other reasons, e.g. through contaminated traps, the transfer of infected $A$. astacus, the crayfish trade, animals preying on crayfish, and even fishing gear (e.g. NYLUND and WESTMAN, 1992). To protect $A$. astacus populations, it is crucial to prevent the plague from spreading from infected waters to good $A$. astacus waters, irrespective of whether the infected waters are " ordinary » plague waters, i.e. populated by $A$. astacus, or $P$. leniusculus waters. To this end, fisheries authorities agreed on a $P$. leniusculus stocking strategy in 1989 (MANNONEN and WESTMAN, 1998). This strategy is currently being revised.

Even though $P$. leniusculus has already been an economic success in numerous water areas (WESTMAN, 2000) and has great economic potential (ACKEFORS, 1999), concern about replacement of the native $A$. astacus should be taken most seriously. The present study clearly shows that stocking with $P$. leniusculus may pose serious risks for the native $A$. astacus. Not only can $P$. leniusculus spread the plague but plague-free stocks are able to outcompete co-existing $A$. astacus. It is therefore vital that water owners and the authorities take protection of the native species into account when introducing $P$. leniusculus into new waters.

Under a number of regulations (those of the EU) and conventions (e.g. the Rio Convention, Bern Convention) Finland is responsible for the conservation of aquatic diversity including the preservation of $A$. astacus, a species considered vulnerable by the IUCN (GROOMBRIDGE, 1993). Preserving $A$. astacus is also of great importance in terms of fishery as only then can its continued participation in crayfish catches and trade be secured. This requires above all the formulation of an $A$. astacus action plan similar to that drawn up for Austropotamobius pallipes in the United Kingdom (PALMER, 1994) and a greater input into research, especially on crayfish plague control and crayfish management. A greater number of direct observations of interactions between sympatric $A$. astacus and $P$. leniusculus populations in different natural environments is also needed before the contribution of the various factors and the interaction between them to native 
$A$. astacus replacement by the introduced $P$. leniusculus can be fully understood. The present study confirms earlier claims (e.g. MORROW, 1990 ; MATHER and STEIN, 1993 ; LODGE and HILL, 1994) that crayfish replacement is difficult to study and is inadequately understood, and that it appears to be a complex interaction of multiple factors.

\section{ACKNOWLEDGEMENTS}

Over the years, many persons have given generously of their time and effort to the various phases of the studies, in particular the following members, past and present, of the Finnish Game and Fish Research Institute : Pekka Ahlfors, Esa Erkamo, Teuvo Järvenpää, Eero Kuittinen, Jarmo Louhimo, Viljo Nylund, Markku Pursiainen, Olli Sumari, Jukka Sutela, Klaus Sundbäck, Jouni Tulonen, Irmeli Wallin, Pia Westman, Tapani Vänttinen and the late Aulis Keinänen. We thank Fiskars Oy for enabling us to work at Lake Slickolampi all these years and Matti Vuorinen for helping us in so many ways. We are also grateful to Taina Kytöaho for helping to draw the figures, Kati Manninen for technical assistance and Gillian Häkli for revising the English.

\section{REFERENCES}

ABRAHAMSSON S., 1964. Pågående och planerad forskning rörande ekologien hos Astacus astacus (Linné) och Pacifastacus leniusculus (Dana) (Summary : Present and planned research concerning the ecology of Astacus astacus (Linné) and Pacifastacus leniusculus (Dana). Svensk Naturvetenskap, 1964, 306-316.

ABRAHAMSSON S., 1965. A method of marking crayfish Astacus astacus Linné in population studies. Oikos, 16, 228-231.

ABRAHAMSSON S., 1966. Dynamics of an isolated population of the crayfish Astacus astacus Linné. Oikos, 17, 96-107.

ABRAHAMSSON S., 1971. Density, growth and reproduction of the crayfish Astacus astacus and Pacifastacus leniusculus in an isolated pond. Oikos, 22, 373380.

ABRAHAMSSON S., 1983. Trappability, locomotion, and diel pattern of activity of the crayfish Astacus astacus and Pacifastacus leniusculus Dana. Freshwater Crayfish, 5, 239-253.

ABRAHAMSSON S.A.A., GOLDMAN C.R., 1970. Distribution, density and production of the crayfish Pacifastacus leniusculus Dana in Lake Tahoe, California-Nevada. Oikos, 21, 83-91.

ACKEFORS H., 1999. The positive effects of established crayfish introductions in Europe. In : GHERARDI F., HOLDICH D.M. (Eds.), Crayfish in Europe as alien species. How to make the best of a bad situation, A.A. Balkema, Rotterdam, 49-61.

AIKEN D.E., WADDY S.L., 1992. The growth process in crayfish. Reviews in Aquatic Sciences, 6, 335-381.

BRINCK P., 1983. Sture Abrahamsson memorial lecture. An ecologist's approach to dealing with the loss of Astacus astacus. Freshwater Crayfish, 5, xxi-xxxvii.

BUTLER M.J., STEIN R.A., 1985. An analysis of the mecahanisms governing species replacement in crayfish. Oecologia, 66, 168-177.

CAPELLI G.M., MUNJAL. B.L., 1982. Aggressive interactions and resource competition in relation to species displacement among crayfish of the genus Orconectes. J. Crust. Biol., 2, 486-492.

CUKERZIS J.M., 1988. Astacus astacus in Europe. In : HOLDICH D.M. and LOWERY R.S. (Eds.), Freshwater Crayfish : biology, management and exploitation. Croom Helm, London, 309-340.

FIRKINS I., HOLDICH D.M., 1993. Thermal studies with three species of freshwater crayfish. Freshwater Crayfish, 9, 241-248. 
FISKERIVERKET, 1993. Möjligheter att öka flodkräftbestånd i svenska vatten. (Summary : Ways of increasing populations of the noble crayfish Astacus astacus in Swedish fresh waters). Information från Sötvattenslaboratoriet, Drottningholm (2), 1-66.

FITZPATRICK J.C., 1977. The statistical relationships of different techniques of measurements in a crayfish species. Freshwater Crayfish, 3, 471-479.

FJÄLLING A., 1995. Crayfish traps in Swedish fisheries. Freshwater Crayfish, 8, 201-214.

FJÄLLING A., FÜRST M., 1988. The development of a fishery for the crayfish Pacifastacus leniusculus in Sweden 1960-86. Freshwater Crayfish, 7, 223-230.

FLINT R.W., 1975. The natural history, ecology and production of the crayfish, Pacifastacus leniusculus, in a subalpine lacustrine environment. Ph.D. thesis. Univ. of California. Davis, CA, $150 \mathrm{p}$.

FLINT R.W., 1977. Seasonal activity, migration and distribution of the crayfish, Pacifastacus leniusculus, in Lake Tahoe. Am. Midl. Nat., 97, 280-292.

FÜRST M., 1977. Introduction of Pacifastacus leniusculus (Dana) into Sweden : methods, results and management. Freshwater Crayfish, 3, 229-247.

GARVEY J.E., STEIN R.A., 1993. Evaluating how chela size influences the invasion potential of an introduced crayfish (Orconectes rusticus). Am. Midl. Nat., 129, 172181.

GHERARDI F., HOLDICH D.M. (Eds.), 1999, Crayfish in Europe as alien species. How to make the best of a bad situation. A.A. Balkema, Rotterdam, $299 \mathrm{p}$.

GROOMBRIDGE B., 1993. 1994 IUCN Red List of threatened animals. World Conservation Monitoring Centre, Cambridge, UK.

HESSEN D.O., 1989. Crayfish food and nutrition. In : SKURDAL J., WESTMAN K., BERGAN P.I. (Eds), Crayfish culture in Europe. Report from the workshop on crayfish culture, 16 - 19 Nov. 1987, Trondheim, Norway, 164-174.

HILL A.M., LODGE D.M., 1994. Diel changes in resource demand: competition and predation in species replacement among crayfishes. Ecology, 75, 2118-2126.

HOBBS III H.H., JASS J.P., HUNER J.V., 1989. A review of global crayfish introductions with particular emphasis on two North American species (Decapoda, Cambaridae). Crustaceana, 56, 299-316.

HOLDICH D.M., READER J.P., ROGERS W.D., HARLIOGLU M., 1995a. Interactions between three species of crayfish (Austropotamobius pallipes, Astacus leptodactylus and Pacifastacus leniusculus). Freshwater Crayfish, 10, 4656.

HOLDICH D.M., REEVE I.D., ROGERS W.D., 1995b. Introduction and spread of alien crayfish in British waters - implications for native crayfish populations. Freshwater Crayfish, 8, 99-112.

JONSSON A., 1995. Life history differences between crayfish Astacus astacus and Pacifastacus leniusculus in embryonic and juvenile development, laboratory experiences. Freshwater Crayfish, 8, 170-178.

JÄRVI T.H., 1910. Über den Krebs (Astacus fluviatilis Rond.) und die Krebsepidemieen in Finland. Acta Soc. Fauna Flora Fennica, 33 (3), 1-41.

LAURENT P.J., PARIS L., 1994. Les mésaventures d'une population de pieds rouges en Morvan. L'Astaciculteur de France, 41, 6-8.

LINDQVIST O.V., HUNER J.V., 1999. Life history characteristics of crayfish : What makes some of them good colonizers? In : GHERARDI F., HOLDICH D.M. (Eds.), Crayfish in Europe as alien species. How to make the best of a bad situation. A.A. Balkema, Rotterdam, 23-30.

LODGE D.M., HILL A.M., 1994. Factors governing species composition, population size, and productivity of cool-water crayfishes. Nordic J. Freshw. Res., 69, 111-136.

LOWERY R.S., 1988. Growth, moulting and reproduction. In : HOLDICH D.M., LOWERY R.S. (Eds.), Freshwater Crayfish : biology, management and exploitation. Croom Helm, London, 83-113.

LOWERY R.S., HOLDICH D.M., 1988: Pacifastacus leniusculus in North America and Europe, with details of the distribution of introduced and native crayfish species in 
Europe. In : HOLDICH D.M., LOWERY R.S. (Eds.), Freshwater Crayfish : biology, management and exploitation. Croom Helm, London, 283-308.

MANNONEN A., WESTMAN K., 1998. Crayfish situation in Finland. In : TAUGBØL T. (ed.), Nordic-Baltic workshop on freshwater crayfish research and management, May 22-26, 1998, Sagadi Training Centre, Estonia. Østlandforsking, ØF-Rapport nr. 26/1998, 29-38.

MASON J.C., 1975. Crayfish production in a small woodland stream. Freshwater Crayfish, 2, 449-479.

MATHER M.E., 1990. Mechanisms of a species replacement in a benthic stream community. -Ph.D. thesis, The Ohio State University. $162 \mathrm{p}$.

MATHER M.E., STEIN R.A., 1993. Direct and indirect effects of fish predation on the replacement of a native crayfish by an invading congener. Can. J.Fish. Aquat.Sci., $50,1279-1288$.

MOMOT W., 1993. The role of exploitation in altering the processes regulating crayfish populations. Freshwater Crayfish, 9, 101-117.

MORROW D.A., 1990. Growth, predation susceptibility, and competition among three Orconectid crayfishes : possible mechanics governing crayfish species replacement in Northern Wisconsin. -MS. thesis, University of Wisconsin.

NYLUND V., WESTMAN K., 1992. Crayfish diseases and their control in Finland. Report from the EIFAC workshop on crayfish management and stocking, 22-23 August 1991, Kuopio, Finland. Finn. Fish. Res., 14, 107-118.

NYSTRÖM P., 1999. The effects of crayfish on interactions in freshwater benthic communities. -Ph.D. thesis, Department of ecology, Limnology, Lund University., $30 \mathrm{p}$.

NYSTRÖM P., BRÖNMARK C., GRANELI W., 1999. Influence of an exotic and native crayfish species on a littoral benthic community. Oikos, 85, 545-553.

OLSEN T.M., LODGE D.M., CAPELLI G.M., HOULIHAN R.J., 1991. Mechanisms of impact of an introduced crayfish (Orconectes rusticus) on littoral congeners, snails, and macrophytes. Can. J. Fish. Aquat. Sci., 48, 1853-1861.

PALMER M., 1994. Action plan for the conservation of the native freshwater crayfish Austropotamobius pallipes in the United Kingdom. Joint Nature Conservation Committee, JNCC Report $n^{\circ} 193,14 p+5 p$.

RICKER W.E., 1975. Computation and interpretation of biological statistics of fish populations. Bulletin of Fisheries Research Board of Canada, 191, 1-382.

RUTLEDGE P.S., PRITCHARD A.W., 1981. Scope for activity in the crayfish Pacifastacus leniusculus. Am. J. Physiol., 240 (Regulatory Integrative Comp. Physiol. 9), R87R92.

SAVOLAINEN R., WESTMAN K., PURSIAINEN M., 1997. Fecundity of Finnish noble crayfish Astacus astacus L., and signal crayfish, Pacifastacus leniusculus, in various natural habitats and in culture. Freshwater Crayfish, 11, 319-338.

STEIN R.A., 1976. Sexual dimorphism in crayfish chelae : functional significance linked to reproductive activities. Can. J. Zool., 54, 220-227.

SVÄRDSON G., 1965. The American crayfish Pacifastacus leniusculus (Dana) introduced into Sweden. Rep. Inst. Freshwater Res., Drottningholm 46, 90-94.

SVÄRDSON G., FÜRST M., FJÄLLING A., 1991. Population resilience of Pacifastacus leniusculus in Sweden. Finnish Fisheries Research, 12, 165-177.

SÖDERBÄCK B., 1991. Interspecific dominance relationship and aggressive interactions in the freshwater crayfishes Astacus astacus (L.) and Pacifastacus leniusculus (Dana). Can. J. Zool., 69, 1321-1325.

SÖDERBÄCK B., 1993. Population regulation in two co-occurring crayfish species. -Ph.D. thesis, Acta Universitatis Upsaliensis 434. Uppsala. 29 p.

SÖDERBÄCK B., 1994a. Interactions among juveniles of two freshwater crayfish species and a predatory fish. Oecologia, 100, 229-235.

SÖDERBÄCK B., 1994b. Reproductive interference between two co-occurring crayfish species, Astacus astacus L. and Pacifastacus leniusculus Dana. Nordich J. Freshw. Res., 69, 137-143. 
SÖDERBÄCK B., 1995. Replacement of the native crayfish Astacus astacus by the introduced species Pacifastacus leniusculus in a Swedish lake: possible causes and mechanisms. Freshwater Biology, 33, 291-304.

TSUKERZIS Ya.M., 1976. Interspecific competition in closely related species of crayfish (Astacus astacus, Astacus leptodactylus, and Pacifastacus leniusculus, Decapoda, Crustacea). Doklady Biological Sciences, Seriya Biologia 119 (1-6) : 283-285. Translated (Plenum Publishing Corporation) from Doklady Akademii Nauk SSSR, 229 (1) : 250-252.

WESTMAN K.,1973. The population of crayfish, Astacus astacus L. in Finland and the introduction of the American crayfish Pacifastacus leniusculus Dana. Freshwater Crayfish, 1, 41-55.

WESTMAN K., 1991. The crayfish fishery in Finland - its past, present and future. Finn. Fish. Res., 12, 187-216.

WESTMAN K., 2000. Comparison of the crayfish Pacifastacus leniusculus Dana, a species introduced into Finland, with the native species, Astacus astacus L., in allopatry and sympatry. - Ph.D. thesis, Riistan ja kalantutkimus, Helsinki. $50 p+157 p$.

WESTMAN K., PURSIAINEN M., 1979. Development of the European crayfish Astacus astacus (L.) and American crayfish Pacifastacus leniusculus (Dana) populations in a small Finnish lake. Freshwater Crayfish, 4, 243-250.

WESTMAN K., WESTMAN P., 1992. Present status of crayfish management in Europe. Report from the EIFAC Workshop on Crayfish Management and Stocking, 22-23 August 1991, Kuopio, Finland. Finn. Fish. Res., 14, 1-22.

WESTMAN K., PURSIAINEN M., VILKMAN R., 1979. A new folding trap model which prevents crayfish from escaping. Freshwater Crayfish, 4, 235-242.

WESTMAN K., SAVOLAINEN R., PURSIAINEN M., 1993a. A comparative study on the growth and moulting of the noble crayfish, Astacus astacus (L), and the signal crayfish Pacifastacus leniusculus (Dana), in a small forest lake in southern Finland. Freshwater Crayfish, 9, 451-465.

WESTMAN K., SAVOLAINEN R., PURSIAINEN M., 1993b. A comparative study on the reproduction of the noble crayfish, Astacus astacus (L), and the signal crayfish Pacifastacus leniusculus (Dana), in a small forest lake in southern Finland. Freshwater Crayfish, 9, 466-476.

WESTMAN K., SAVOLAINEN R., PURSIAINEN M., 1995. Development of European noble crayfish Astacus astacus (L.) and American signal crayfish Pacifastacus leniusculus (Dana) populations in a small Finnish lake - a 20 year study. Freshwater Crayfish, 8, 235-248.

WESTMAN K., SAVOLAINEN R., PURSIAINEN M., 1999. Development of the introduced North American signal crayfish, Pacifastacus leniusculus (Dana), population in a small Finnish forest lake in 1970-1997. Boreal Env. Res., 4, 387-407.

WILLMAN E.J., HILL A.M., LODGE D.M., 1994. Response of three crayfish congeners (Orconectes spp.) to odors of fish carrion and live predatory fish. Amer. Midl. Nat., 132, 44-51. 
